\section{Correspondence}

https://doi.org/10.11646/zootaxa.5052.4.7

http://zoobank.org/urn:lsid:zoobank.org:pub:3552B114-2CAF-40B7-9961-18B16B06E478

\title{
Macoma Leach, 1819 (Mollusca: Bivalvia: Tellinidae): the unavailability of Limecola Brown, 1844, and Limicola Leach, 1852
}

\author{
JAN KRESTEN NIELSEN \\ Department of Geological Engineering, Süleyman Demirel University, Isparta, Turkey. \\ ま"taphofacies@hotmail.com; @il https://orcid.org/0000-0003-0637-3492
}

Tellinidae Blainville, 1814, is a diverse family of marine to brackish-water clams which contains, among others, the large genus Macoma Leach, 1819 (here: 1819a), within the subfamily Macominae Olsson, 1961. The genus' taxonomy, systematics, ecology and palaeontology has been studied for decades (e.g. Coan 1971: 19; Meijer 1993: 297; Coan \& Scott 1997: 15; Hummel et al. 2001: 189; Huber et al. 2015: 742) and several benthic communities are named after it, such as the circumpolar Macoma calcarea community and the boreal Macoma balthica community (Thorson 1957: 505). Genetic studies have also been conducted by Meehan (1985: 69), Meehan et al. (1989: 235), Väinölä (2003: 935), Nikula et al. (2007: 928), Saunier et al. (2014: 1), Layton et al. (2016: 282), and Yurchenko et al. (2018: 58). Nevertheless, the nomenclature and classification of Macoma and its subordinate taxa remain unresolved. The present study provides a brief survey of the nomenclatorial history of the genus and type species; it also addresses the usage of Limicola Leach, 1852, Macroma as of Gray (1825) and others, and of Limecola, which has been recently revived as a valid genus by Huber et al. (2015: 290, 291, 737).

Macoma and M. tenera: The generic name Macoma was published four times during 1819, firstly in the first edition of the book "A Voyage of Discovery..." together with a single species M. tenera (Leach, 1819: 1xii) (here: 1819a) which thus becomes the type species by monotypy. The $1^{\text {st }}$ edition is authored by Ross. The genus and species in question, however, are described in Appendix II titled "List of invertebrate animals ...; corrected by W. E. Leach" where he figures as the author of the genus Macoma but not specifically of tenera, in contrast to other species which he marked as "(new species)".

Appendix IV by Leach (1819b: 175) of the $2^{\text {nd }}$ edition of the book essentially repeats the text of the $1^{\text {st }}$ edition. Because its title reads "Descriptions of the new species of animals ... by Dr. W. E. Leach" (1819b: 169), however, the specific name tenera as well can be assumed to be authored by Leach ( $c f$. Article 50.1.1 of the ICZN 1999: 52).

The date of the original publication remains problematic, though, because the cover pages of both the $1^{\text {st }}$ and $2^{\text {nd }}$ edition only state the year 1819 lacking other hints in these volumes towards the month and day of their publication. But Leach (1819c: 462) published another version of his "Descriptions ..." in the French Journal de Physique, de Chimie et d'Histoire Naturelle, vol. 88, in June 1819 and in which he referred to the $1^{\text {st }}$ edition of the "Voyages ..." (Leach 1819c: 463; taxa described on p. 465) suggesting that the date of publication of the $1^{\text {st }}$ edition must be no later than the end of June 1819. Lending further support to this interpretation, a footnote in Leach (1819d: 201) indicates that the $2^{\text {nd }}$ edition was published contemporaneously or before end of September 1819. Based on this indirect evidence and Article 21.3.1 of the code (ICZN 1999: 22), it seems that the date of publication for Macoma and M. tenera must be deemed to be June 30, 1819. Concordantly with this interpretation, most later publications coincide with Macoma and $M$. tenera Leach, 1819. The type species, however, is usually considered a junior synonym of Tellina calcarea Gmelin, 1791 (e.g. Carpenter 1857: 221; Dall 1900: 299; Keen 1969: N623; Coan 1971: 19; Coan et al. 2000: 408).

Macroma: The combination Macroma [sic] tenera Leach appeared in Gray (1825: 136; 1847: 186), Forbes \& Hanley (1848-1853: 307) and Middendorff (1851: 257). This combination was also mentioned by Jeffreys (1863: 378, 390) although he was aware that Mörch (1853: 11) spelled the generic name as Macoma. Gray's (1825) Macroma was regarded an inadvertent spelling error (lapsus calami) by Scudder (1882: 198), Neave (1940: 14) and Vokes (1980:145). 
Limecola: This name has been variably attributed to Brown (1844) or Leach in Brown (1844) in the literature. But the name was never published by Leach himself so that Brown (1844) has to be regarded as the author (cf. Article 50.1.1, ICZN 1999: 52). However, Brown (1844: 101, pl. xl, fig. 14) neither adopted Limecola as a valid taxon name nor treated it as a senior homonym, but rather referred to "Limecola solidula, Leach, MSS., p. 7" as a junior synonym of Tellina solidula sensu Brown (1827: pl. xvi, fig. 14) (Brown 1844: 101).

According to present knowledge, Limecola was never considered a valid name before 1961, meaning that the requirements for availability established in Article 11.6.1 (ICZN 1999: 11) are not met. Thus, Vokes (1967: 284; 1980: 145) found Limecola to be invalid nomenclatorially, whereas Keen (1969: N623) and Higo et al. (1999: 488) assumed that Limecola is a junior synonym of Macoma. Contrary to these views, Huber et al. (2015: 737) claimed Limecola to be a valid genus name.

Limicola: This genus name was introduced by Leach (1852: 296) to cover the British Limicola carnaria [sic] referring to Tellina carnaria sensu Pennant (1777), which he thought was not identical with T. carnaria Linnaeus, 1758 (p. 676). Later, Dall (1900: 292) deemed the generic name Limicola Leach, 1852, not Koch, 1816, as synonymous with the subgenus Macoma (Macoma) Leach, 1819, with M. tenera Leach (= T. calcarea Gmelin, 1791) as the type. Vokes (1967: 284; 1980: 143) stated that Limicola Leach, 1852, and Limicola Gray, 1857, are both invalid as they are junior homonyms of Limicola Koch, 1816, Class Aves.

Tellina vs. Macoma vs. Limecola: The original combination of the Baltic Tellina balthica Linnaeus, 1758 (p. 677 ), is a senior synonym of T. carnaria sensu Pennant, 1777 (p. 88, pl. xlix, fig. 32, non Linnaeus, 1758, = Strigilla), T. rubra Costa, 1778 (p. 211, pl. xii, fig. 4), and T. solidula Pulteney, 1799 (p. 29) (cf. Montagu 1803: 63; Brown 1844: 101; Forbes \& Hanley 1848-1853: 304; Römer 1871: 15, 16; Oliver \& Morgenroth 2018: 299).

The combination Macoma balthica (Linnaeus, 1758) (baltica being a lapsus calami) has been widely used until today (e.g. Mörch 1853:12; Dall 1900: 298; Jensen \& Spärck 1934: 128; Thorson 1957: 505; Rasmussen 1973: 307; Tebble 1976: 149, pl. 9, figs. f, g; Meijer 1993: 297; Jensen \& Knudsen 1995: 45; Kafanov et al. 1997: 298; Hummel et al. 2001: 189; Väinölä 2003: 935; Genelt-Yanovskiy et al. 2018: 13). Another combination is Macoma (Macoma s.1.) balthica (Linnaeus, 1758) used by Coan \& Scott (1997: 16).

In recent years, however, some authors have begun to use the combination Limecola balthica (Linnaeus, 1758) as the presumed valid name for the Baltic tellinid. That usage, which probably began with Huber et al. (2015: 737) (see above), now appears in more than 25 publications by at least 10 authors (e.g. Beukema et al. 2017: 1; Pante et al. 2017: 226; Oliver \& Morgenroth 2018: 299; Yurchenko et al. 2018: 58). Since 2015, the lack of consensus is reflected by the instability of generic and subgeneric naming such as "Macoma (Limecola) balthica" by Ducrotoy et al. (2019: 584) and "Limecola (Macoma) balthica" by Beukema et al. (2017: 1), Ehrnsten et al. (2019: 36) and Thornton et al. (2019: 708).

As mentioned before, Huber et al. (2015: 737) regarded Limecola a distinct genus from Macoma. Yet, they placed the combination Limecola balthica in a Macoma-group including Macoma and other genera, without recognizing any subgenera or subspecies. However, the level of subspecies has been found useful in order to explain genetic lineages and hybridization of the North Atlantic $M$. balthica complex, commonly in relation to trans-Arctic invasions from the Pacific (e.g. Meehan 1985; 69; Väinölä 2003: 935; Nikula et al. 2007: 928; Saunier et al. 2014: 1; Layton et al. 2016 : 282). In contrast, placing M. balthica and M. calcarea into different genera is unproven genetically. It still remains uncertain how much the two species differ from each other and at which level the separation between them should be implemented in systematic classification.

Macoma s.s. vs. Macoma s.1.: Concerning the distinction between Macoma balthica and M. calcarea, Huber et al. (2015: 737) emphasized the characteristics of the periostracum, shell color, and pallial sinus. However, thickness of the periostracum is related to water temperature (Olsson 1961: 410) serving as protection of the calcareous part of the shell against higher corrosion in cold waters (Cox 1969: N74) and shell color is very variable in M. balthica (Tebble 1976: 149; Kafanov et al. 1997: table 3; Coan et al. 2000: 417). Both characteristics are thus inadequate for a generic distinction. The pallial sinus was used by Coan et al. (2000: 409, 417) for a sort of "supraspecific" distinction between Macoma (Macoma s.s.) calcarea and Macoma s.l. balthica [sic]. The former is characterized by sinuses detached from the pallial line, being deep in the left valve and moderately deep in the right valve. In M. balthica, the sinus is deep in both valves and not detached (Coan et al. 2000: 409, 417). 
According to Marinho \& Arruda (2021: 1, table 4), pallial sinuses and adductor muscle scars might be useful to distinguish some species of the subfamily Macominae, whereas the shell shape and size are related to life habits. In contrast, Kafanov et al. (1997: 298) concluded that the pallial lines and sinuses as well as the muscle scars are insignificant to separate $M$. balthica and $M$. calcarea, due to their adaptive nature. It thus appears that only molecular phylogeny can solve this stalemate, which could then also address the potential polyphyly of the subfamily Macominae (cf. Coan et al. 2000: 398, 408).

\section{Acknowledgements}

Kathe Jensen (Natural History Museum of Denmark, University of Copenhagen) is thanked for valuable discussion. Nikolaus Malchus (Institut Català de Paleontologia Miquel Crusafont, Bellaterra), Simon Schneider (CASP, Cambridge) and Barbara Studencka (Polish Academy of Sciences, Warsaw) provided constructive critical reviews.

\section{References}

Beukema, J.J., Dekker, R. \& Drent, J. (2017) Dynamics of a Limecola (Macoma) balthica population in a tidal flat area in the western Wadden Sea: effects of declining survival and recruitment. Helgoland Marine Research, 71 (18), 1-12. https://doi.org/10.1186/s10152-017-0498-7

Blainville, M.H.[H.-M.D.] de (1814) Mémoire sur la classification méthodique des animaux mollusques, et établissement d'une nouvelle considération pour y parvenir. Bulletin des Sciences, par la Société Philomatique de Paris, 1814, 175-180. [in French]

Brown, T. (1827) Illustrations of the conchology of Great Britain and Ireland. W.H. Lizars and D. Lizars, Edinburgh, S. Highley, London, [2] + v pp., 52 pls. https://doi.org/10.5962/bhl.title.62824

Brown, T. (1844) Illustrations of the recent conchology of Great Britain and Ireland with the description and localities of all the species, marine, land, and fresh water. $2^{\text {nd }}$ Edition, Greatly Enlarged. Smith, Elder \& Co., London, xiii +144 pp., 62 pls. https://doi.org/10.5962/bhl.title.10336

Carpenter, P.P. (1857) Report on the present state of our knowledge with regards to the Mollusca of the West coast of North America. Report of the British Association for the Advancement of Science, 1856, 1-4 (list of plates) + 159-368, pls. VI-IX. https://doi.org/10.5962/bhl.title.60613

Coan, E.V. (1971) The Northwest American Tellinidae. The Veliger, 14 (Supplement), 1-63.

Coan, E.V. \& Scott, P.H. (1997) Checklist of the marine bivalves of the Northeastern Pacific Ocean. Santa Barbara Museum of Natural History, Contributions in Science, 1, 1-28.

Coan, E.V., Scott, P.V. \& Bernard, F.R. (2000) Bivalve seashells of western North America. Marine bivalve mollusks from Arctic Alaska to Baja California. Santa Barbara Museum of Natural History Monographs, Studies in Biodiversity, 2, i-viii $+1-764$.

Cox, L.R. (1969) General features of Bivalvia. In: Moore, R.C. (Ed.), Treatise on invertebrate paleontology. Part N. Vol. 1. Mollusca 6. Bivalvia. The Geological Society of America and the University of Kansas, Lawrence, pp. N2-N129.

Costa, E.M. da (1778) Historia naturalis testaceorum Britanniae, or, the British conchology; containing the descriptions and other particulars of natural history of the shells of Great Britain and Ireland. Millan, B. White, Elmsley, and Robson, London, $x i i+[2]+254+$ vii $+[1]$ pp., XVII pls.

Dall, W.H. (1900) Synopsis of the family Tellinidae and of the North American species. Proceedings of the United States National Museum, 23 (1210), 285-326, 3 pls. https://doi.org/10.5479/si.00963801.23-1210.285

Ducrotoy, J.-P., Elliott, M., Cutts, N.D., Franco, A., Little, S., Mazik, K. \& Wilkinson, M. (2019) Temperate estuaries: their ecology under future environmental changes. In: Wolanski, E., Day, J.W., Elliott, M. \& Ramachandran, R. (Eds.), Coasts and estuaries. The future. Elsevier, Amsterdam, pp. 577-594. https://doi.org/10.1016/B978-0-12-814003-1.00033-2

Ehrnsten, E., Norkko, A., Timmermann, K. \& Gustafsson, B.G. (2019) Benthic-pelagic coupling in coastal seas - Modelling macrofaunal biomass and carbon processing in response to organic matter supply. Journal of Marine Systems, 196, 3647. https://doi.org/10.1016/j.jmarsys.2019.04.003

Forbes, E. \& Hanley, S. (1848-1853) A history of British Mollusca and their shells. Vols. 1 - 4. John van Voorst, London, lxxx + 486 pp., [64] pls. (Vol. I), viii + 557 pp. (Vol. II), x + 616 pp. (Vol. III), vi + 301 pp., 133 pls. (Vol. IV).

Genelt-Yanovskiy, E., Aristov, D., Poloskin, A. \& Nazarova, S. (2018) Trends and drivers of Macoma balthica L. dynamics in Kandalaksha Bay, the White Sea. Journal of the Marine Biological Association of the United Kingdom, 98 (1), 13-24. https://doi.org/10.1017/S0025315417001473

Gmelin, J.F. (1791) Classis VI. Vermes. In: Gmelin, J.F. (Ed.), Caroli a Linnaei Systema Naturae per regna tria naturae, 
secundum classes, ordines, genera, species, cum characteribus, differentiis, synonymis, locis. Tomus I. Pars VI. Editio decima tertia, aucta, reformata. G.E. Beer, Lipsiae, pp. 3021-3910.

https://doi.org/10.5962/bhl.title.36932

Gray, J.E. (1825) A list and description of some species of shells not taken notice of by Lamarck. The Annals of Philosophy, New Series, IX (II), 134-140.

Gray, J.E. (1847) A list of genera of recent Mollusca, their synonyma and types. Proceedings of the Zoological Society of London, 15, 129-219.

Gray, M.E. (1857) Figures of molluscous animals, selected from various authors. Etched for the use of students. Vol. V. Conchifera and Brachiopoda. Longman, Brown, Green, Longmans, and Roberts, London, pp. 1-13 (Figures of molluscous animals) + 15-49 (Systematic arrangement of the figures, continued from vol. IV), pls. 313-381. https://doi.org/10.5962/t.171558

Higo, S., Callomon, P. \& Goto, Y. (1999) Catalogue and bibliography of the marine shell-bearing Mollusca of Japan. Gastropoda, Bivalvia, Polyplacophora, Scaphopoda. Elle Scientific Publications, Osaka, 749 pp.

Huber, M., Langleit, A. \& Kreipl, K. (2015) Tellinidae. In: Huber, M. (Ed.), Compendium of bivalves 2. A full-color guide to the remaining seven families. A systematic listing of 8'500 bivalve species and 10'500 synonyms. ConchBooks, Harxheim, pp. 564-745, CD-ROM.

Hummel, H., Amiard, J.C., Amiard-Triquet, C., Bogaards, R.H., Löhr, A.J. \& Coutaud, G. (2001) A comparison of the ecophysiological response on copper in Baltic clams from different populations in Europe. Vie \& Milieu-Life \& Environment, 51 (4), 189-194.

ICZN [International Commission on Zoological Nomenclature] (1999) International Code of Zoological Nomenclature. Fourth edition. The International Trust for Zoological Nomenclature, London, xxix $+306 \mathrm{pp}$. https://doi.org/10.5962/bhl.title.50608

Jeffreys, J.G. (1863) British conchology, or an account of the Mollusca which now inhabit the British Isles and the surrounding seas. Volume II. Marine shells, comprising the Brachiopoda, and Conchifera from the family of Anomiidae to that of Mactridae. John van Voorst, London, xiv + 465 pp., viii pls. https://doi.org/10.5962/bhl.title.4110

Jensen, K.R. \& Knudsen, J. (1995) Annotated checklist of recent marine molluscs of Danish waters. H.C. Ørsted Tryk, Copenhagen, 73 pp.

Jensen, A.S. \& Spärck, R. (1934) Bløddyr II. Saltvandsmuslinger. G.E.C. Gads Forlag, København, Danmarks Fauna, 40, 1-208. [in Danish]

Kafanov, A.I., Danilin, D.D. \& Moshchenko, A.V. (1997) Morphometrical analysis of taxonomical characteristics of bivalve mollusks of the genus Macoma. Russian Journal of Marine Biology, 23 (6), 298-307.

Keen, A.M. (1969) Superfamily Tellinacea de Blainville, 1814. In: Moore, R.C. (Ed.), Treatise on invertebrate paleontology. Part N. Vol. 2. Mollusca 6. Bivalvia. The Geological Society of America and the University of Kansas, Lawrence, pp. N613-N643.

Koch, K.L. (1816) Die Säugthiere und Vögel Baierns. Steinische Buchhandlung, Nürnberg, xlvii + 435 pp., 13 pls. [in German] https://doi.org/10.5962/bhl.title.50218

Layton, K.K.S., Martel, A.L. \& Hebert, P.D.N. (2016) Geographic patterns of genetic diversity in two species complexes of Canadian marine bivalves. Journal of Molluscan Studies, 82, 282-291. https://doi.org/10.1093/mollus/eyv056

Leach, W.E. (1819a) A list of invertebrate animals, discovered by His Majesty's ship Isabella, in a voyage to the Arctic regions; corrected by W. E. Leach. In: Ross, J., A voyage of discovery, made under the Orders of the Admiralty, in His Majesty's ships Isabella and Alexander, for the purpose of exploring Baffin's Bay, and inquiring into the probability of a North-West Passage. Appendix II. John Murray, London, pp. lxi-lxiv.

Leach, W.E. (1819b) Descriptions of the new species of animals, discovered by His Majesty's ship Isabella, in a voyage to the Arctic regions; by Dr. W. E. Leach. In: Ross, J., A voyage of discovery, made under the orders of the admiralty, in His Majesty's ships Isabella and Alexander, for the purpose of exploring Baffin's Bay, and enquiring into the probability of a North-West Passage. Vol. II. $2^{\text {nd }}$ Edition. Appendix IV. Longman, Hurst, Rees, Orme, and Brown, London, pp. 169-179.

Leach, W.E. (1819c) Descriptions des nouvelles espèces d'Animaux découvertes par le vaisseau Isabelle dans un voyage au pôle boréal. Journal de Physique, de Chimie et d'Histoire Naturelle, 88, 462-467. [June]

Leach, W.E. (1819d) Descriptions of the new species of animals discovered by his Majesty's Ship Isabella, in a voyage to the Arctic regions. Annals of Philosophy, 14 (3), 201-206. [September]

Leach, W.E. (1852) A synopsis of the Mollusca of Great Britain, arranged according to their natural affinities and anatomical structure. John van Voorst, London, xvi +376 pp., 13 pls. https://doi.org/10.5962/bhl.title.13170

Linnaeus, C. (1758) Systema naturae per regna tria naturae, secundum classes, ordines, genera, species, cum characteribus, differentiis, synonymis, locis. Tom. I. Editio decima, reformata. Laurentii Salvii, Holmiae, [4] + 824 pp. https://doi.org/10.5962/bhl.title.542

Marinho, T.A. \& Arruda, E.P. (2021) Shell-specific differentiation: how geometric morphometrics can add to knowledge of Macominae species (Tellinidae, Bivalvia). Marine Biodiversity, 51 (40), 1-14. 
https://doi.org/10.1007/s12526-021-01176-x

Meehan, B.W. (1985) Genetic comparison of Macoma balthica (Bivalvia: Tellinidae) from the eastern and western North Atlantic Ocean. Marine Ecology Progress Series, 22, 69-76.

https://doi.org/10.3354/meps022069

Meehan, B.W., Carlton, J.T. \& Wenne, R. (1989) Genetic affinities of the bivalve Macoma balthica from the Pacific coast of North America: evidence for recent introduction and historical distribution. Marine Biology, 102, 235-241. https://doi.org/10.1007/BF00428285

Meijer, T. (1993) Stratigraphical notes on Macoma (Bivalvia) in the southern part of the North Sea Basin and some remarks on the arrival of Pacific species. Scripta Geologica, Special Issue, 2, 297-312.

Middendorff, A.T. von (1851) Meeres-Mollusken. In: Middendorff, A.T. von (Ed.), Reise in den äussersten Norden und Osten Sibiriens. Band II. Zoologie. Theil 1. Buchdruckerei der Kaiserlichen Akademie der Wissenschaften, St. Petersburg, pp. 163-464. [in German]

Montagu, G. (1803) Testacea Britannica or natural history of British shells, marine, land, and fresh-water, including the most minute: systematically arranged and embellished with figures. Vols. 1 \& 2. J.S. Hollis, Romsey, 606 pp. xvi pls. [pp. i-xxxvii + 1-291, pp. 293-606, xvi pls.] https://doi.org/10.5962/bhl.title.33927

Mörch, O.A.L. (1853) Catalogus conchyliorum quae reliquit D. Alphonso d'Aguirra \& Gadea Comes de Yoldi, regis daniae cubiculariorum princeps, ordinis dannebrogici in prima classe \& ordinis caroli tertii eques. Fasciculus secundus. Acephala. Annulata cirripedia. Echinodermata. Ludovici Kleinii, Hafniae, [2] + $74+[2]$ pp. https://doi.org/10.5962/bhl.title.12921

Neave, S.A. (Ed.) (1940) Nomenclator zoologicus. A list of the names of genera and subgenera in zoology from the tenth edition of Linnaeus 1758 to the end of 1935. Vol. III M-P. The Zoological Society of London, London, $1065 \mathrm{pp}$. https://doi.org/10.2307/1439031

Nikula, R., Strelkov, P. \& Väinölä, R. (2007) Diversity and trans-arctic invasion history of mitochondrial lineages in the North Atlantic Macoma balthica complex (Bivalvia: Tellinidae). Evolution, 61 (4), 928-941. https://doi.org/10.1111/j.1558-5646.2007.00066.x

Oliver, P.G. \& Morgenroth, H. (2018) Additional type and other notable specimens of Mollusca from the Montagu collection in the Royal Albert Memorial Museum \& Art Gallery, Exeter. Zoosystematics and Evolution, 94 (2), 281-303. https://doi.org/10.3897/zse.94.24776

Olsson, A.A. (1961) Mollusks of the tropical eastern Pacific, particularly from the southern half of the Panamic-Pacific faunal province (Panama to Peru). Panamic-Pacific Pelecypoda. Paleontological Research Institution, Ithaca, New York, 574 pp, $86 \mathrm{pls}$. https://doi.org/10.5962/bhl.title.6853

Pante, E., Poitrimol, C., Saunier, A., Becquet, V. \& Garcia, P. (2017) Putative sex-linked heteroplasmy in the tellinid bivalve Limecola balthica (Linnaeus, 1758). Journal of Molluscan Studies, 83 (2), 226-228. https://doi.org/10.1093/mollus/eyw038

Pennant, T. (1777) British zoology. Vol. IV. Crustacea. Mollusca. Testacea. Benjamin White, London, viii + 154 pp., 93 pls. https://doi.org/10.5962/bhl.title.62481

Pulteney, R. (1799) Catalogues of the birds, shells, and some of the more rare plants, of Dorsetshire. From the new and enlarged edition of Mr. Hutchins's history of that county. J. Nichols, London, [1] + $92 \mathrm{pp}$.

Römer, E. (1871) Die Tellinen der XII. Auflage des Systema naturae von Linné. In: Programm der höheren Bürgerschule zu Cassel für das Schuljahr 1870|71. Friedr. Scheel, Cassel, pp. 1-18. [in German] https://doi.org/10.5962/bhl.title.12144

Rasmussen, E. (1973) Systematics and ecology of the Isefjord marine fauna (Denmark): With a survey of the eelgrass (Zostera) vegetation and its communities. Ophelia, 11, $\mathrm{i}-\mathrm{xvi}+1-495$.

https://doi.org/10.1080/00785326.1973.10430115

Saunier, A., Garcia, P., Becquet, V., Marsaud, N., Escudié, F. \& Pante, E. (2014) Mitochondrial genomes of the Baltic clam Macoma balthica (Bivalvia: Tellinidae): setting the stage for studying mito-nuclear incompatibilities. BMC Evolutionary Biology, 24 (259). [published online]

https://doi.org/10.1186/s12862-014-0259-z

Scudder, S.H. (1882) Nomenclator zoologicus. An alphabetical list of all generic names that have been employed by naturalists for recent and fossil animals from the earliest times to the close of the year 1879. Bulletin of the United States National Museum, 19, i-xxi + 1-340. https://doi.org/10.5962/bhl.title.1143

Tebble, N. (1976) British bivalve seashells. A handbook for identification. $2^{\text {nd }}$ Edition. British Museum (Natural History), Her Majesty's Stationary Office, Edinburghn, 212 pp., 12 pls.

Thornton, A., Herbert, R.J.H., Stillman, R.A. \& Franklin, D.J. (2019) Macroalgal mats in a eutrophic estuarine marine protected area: implications for benthic invertebrates and wading birds. In: Humphreys, J. \& Clark, R.W.E. (Eds.), Marine protected areas: science, policy and management. Elsevier, Amsterdam, pp. 703-727.

https://doi.org/10.1016/B978-0-08-102698-4.00036-8

Thorson, G. (1957) Bottom communities (sublittoral or shallow shelf). In: Hedgepeth, J.W. (Ed.), Treatise on marine ecology 
and paleoecology. Geological Society of America, Memoir, 67 (1), pp. 461-534.

https://doi.org/10.1130/MEM67V1-p461

Väinölä, R. (2003) Repeated trans-Arctic invasions in littoral bivalves: molecular zoogeography of the Macoma balthica complex. Marine Biology, 143, 935-946. https://doi.org/10.1007/s00227-003-1137-1

Vokes, H.E. (1967) Genera of the Bivalvia: A systematic and bibliographic catalogue. Bulletins of American Paleontology, 51 (232), 103-394.

Vokes, H.E. (1980) Genera of the Bivalvia: A systematic and bibliographic catalogue. Revised, updated. Paleontological Research Institution, Ithaca, New York, xxvii + $307 \mathrm{pp}$.

Yurchenko, A.A., Katolikova, N., Polev, D., Shcherbakova, I. \& Strelkov, P. (2018) Transcriptome of the bivalve Limecola balthica L. from Western Pacific: A new resource for studies of European populations. Marine Genomics, 40, 58-63. https://doi.org/10.1016/j.margen.2018.03.007 